\title{
PEMBERDAYAAN PEREMPUAN DALAM MEMAHAMI KOMUNIKASI PEMASARAN PADA MEDIA ONLINE (KONSEP E-COMMERCE) DI GPDI SEJAHTERA JUNREJO BATU MALANG
}

\author{
Gatut Priyowidodo ${ }^{1}$, Yustisia D. Sari ${ }^{1}$, Inri Inggrit I. ${ }^{1}$, \\ ${ }^{1}$ Department of Communication, Petra Christian University, \\ Jl. Siwalankerto 121-131, Surabaya 60236, Indonesia \\ * Penulis korespondensi; E-mail: gatpri@petra.ac.id
}

\begin{abstract}
Abstrak: Kegiatan pengabdian masyarakat yang bertemakan pemberdayaan perempuan dalam memahami komunikasi pemasaran pada media online (konsep e-commerce) di GPDI Sejahtera Junrejo Batu Malang adalah dalam rangka perwujudan tanggung jawab pendidik pada masyarakat selaku stakeholder. Tujuan kegiatan ini adalah Persekutuan Perempuan di GPDI Sejahtera Batu Malang terbentuk ketrampilan melek informasi, mampu mengelola informasi serta memahami komunikasi pemasaran dalam bentuk shopping online sebagai konsep e-commerce. Sasaran kegiatan ini adalah perempuan gereja yang terwadahi oleh Persekutuan Perempuan (PKP) di GPDI Sejahtera Junrejo Batu Malang sebanyak 30 orang. Metode yang digunakan adalah pelatihan media informasi dan komunikasi pemasaran, serta edukasi terkait e-commerce dalam konsep shopping online. Waktu pelaksanaan kegiatan dalam kurun waktu satu tahun. Indikator keberhasilan ibu-ibu memiliki pemahaman mengenai komunikasi pemasaran, pemahaman terkait e-commerce serta bisnis shopping online. Adapun output kegiatan ini adalah publikasi/artikel dalam jurnal pengabdian masyarakat.
\end{abstract}

Kata kunci: Pemberdayaan Perempuan, komunikasi pemasaran, e-commerce, GPDI Sejahtera Junrejo Batu Malang.

\begin{abstract}
The activity of community service that themed women empowerment in understanding marketing communication on online media (e-commerce concept) in GPDI Sejahtera Junrejo Batu Malang is in order to embodiment the responsibility of educators on society As stakeholders. The purpose of this activity is the fellowship of women in the GPDI Sejahtera Batu Malang formed information literacy skills, able to manage information and understand marketing communication in the form of online shopping as an e-commerce concept. The target of this activity is the women of the Church, which is affected by the women's Fellowship (PKP) in the GPDI Sejahtera Junrejo Batu Malang as many as 30 people. The methods used are the training of information media and marketing communication, as well as e-commerce related education in the concept of online shopping. The time of activity is within one year. A success indicator of mothers has a understanding on marketing communication, understanding of e-commerce and online shopping businesses. The output of this activity is the publication/article in the Journal of Community Service.
\end{abstract}

Keywords: Women empowerment, marketing communication, e-commerce, GPDI Sejahtera, Junrejo Batu Malang

\section{PENDAHULUAN}

Pemanfaatan kemajuan teknologi informasi di Indonesia tidak hanya dimonopoli oleh masyarakat perkotaan tetapi juga sudah merambah di wilayah pedesaan. Hingga saat ini, internet telah digunakan di berbagai negara di dunia. Iternet mulai masuk ke Indonesia pada tahun 1992 hingga 1994 dan kini telah menjalar ke berbagai sektor kehidupan manusia. Internet bahkan telah menjadi kebutuhan dalam berbagai kegiatan sehari-hari, hingga mun- cul anggapan tanpa internet, segala hal menjadi tidak dapat digunakan. Dari data yang ditunjukkan, populasi masyarakat di Indonesia sekitar 255, 5 juta orang, data didapatkan sekitar 72,2 juta orang sebagai pengguna internet aktif dan pengguna media sosial sekitar 74 orang. hal yang yang menarik dalam data tersebut adalah pemakai mobile phone atau handphone ternyata adalah sekitar 307,2 juta perangkat. Angka tersebut melebihi jumlah populasi, sebabbnya masing-masing indovidu pada saat ini dapat menggnakan lebih dari 
satu mobile phone atau handphone sesuai keperluannya. (http://binus.ac.id/2015/04/pengaruh-internet-dalam-fenomena-digitalisasi-marketing/, 2016). Dari data diatas menunjukkan bahwa fenomena digitilsasi marketing memberikan dampak yang signifikan terhadap perkembangan teknologi kini, dimana manusia hidup dalam ruang internet sehingga semua kegiatan manusia tidak jauh dari penggunaan internet sebagai kegiatan online. Bahkan yang lebih ekstrm, jejaring sosial telah menjadi rumah yang nyaman bagi manusia, hampir semua dapat dilakukan melalui jejaring sosial.

Dari data diatas menunjukkan perkembangan yang cukup pesat pada lima tahun terakhir ini, akan semakin dirasakan manfaatnya jika ada pihak-piahk tertentu yang memiliki komitmen untuk memberi pencerahan bahwa internet adalah wahana binis masa sekarang dan masa depan yang sangat prospektif. Siapapun tanpa kevuali, baik mereka yang diperkotaan maupun pedesaan harus berani mengambil sisi postif demi peningkatan pendapatan secara ekonomi. Pada era inilah, masyarakat harus dididik memiliki kesadaran akan informasi atau information literacy. Burchinal (1976) mengemukakan information literacy "untuk menjadi orang yang melek informasi dibutuhkan penguasaan sejumlah ketrampilan baru, antara lain kemampuan untuk menempatkan dan menggunakan informasi untuk keperluan memecahkan masalah dan mengambil keputusan secara lebih efektif'. Pentingnya information literacymemunculkan kesadaran baru yang telah mendorong banyak profesional informasi dan organisasi-organisasi untuk memahami dan menerima informasi dengan baik. Melalui kesadaran informasi yang baik, maka peluang untuk terjun dalam bisnis yang bergerak di wilayah akan menjadi semakin baik. Kuncinya sekarang adalah menstimuli dan mengubah pola perilaku kelompok-kelompok masyarakat yang semula hanya berorentasi konsumtif terhadap internet bergeser dengan pola perilaku produktif. Ketika media mempengaruhi perilaku manusia untuk berubah, hal ini menjadi alasan penting bagaimana sebuah organisasi berhasrat untuk mempengaruhi atau mengubah perilaku seseorang. Di era ini, $e$ commerce memberikan peluang besar bagi masyarakat untuk merubah perekonomian. Terungkap melalui survei, masyarakat yang mengakses internet sebesar 98\%, diantaranya membeli produk fashion sebesar $37 \%$, pemesanan ttavel $20 \%$, music/ video dan film $20 \%$, elektronik $20 \%$ dan pembelian buku 8 persen.

Fenomena ini memberikan pandangan, untuk mengubah masyarakat semakin membuka diri dan sadar bahwa peluang-peluang ini menjadikan nilai tambah bagi perekonomian. Dalam hal ini penulis mengajak perempuan-perempuan gereja untuk sadar akan pentingnya peluang e-commerce bagi dunia bisnis, dan sekaligus penulis memberikan informasi mengenai bagaimana cara mengkomunikasikan produk-produk yang yang mereka buat nantinya.

\section{PERMASALAHAN MITRA}

Gereja Pantekosta di Indonesia (GPDI) tidak terlepas dari kedatangan dari kedatangan dua keluarga missionaris dari Gereja Bethel Temple Seattle, USA ke Idonesia pada tahun 1921 yaitu Rev. Richard Van Klaveren keturunan Belanda yang berimigrasi ke Amerika. Dari Bali maka pelayanan beralih ke Surabaya di pulau Jawa tahun 1922, karena kamjuan yang pesat maka tanggal 4 Juni 1942 pemerintahan Hindia Belanda mengakui eksitensi "De Pinkster Gemeente in Nederlandsch Indie" sebagai sebuah "Vereeniniging" (perkumpulan) yang sah. Sampai akhirnya kini Gereja Pantekosta di Indonesia perkembangan semakin besar dan bertumbuh sangat pesat diberbagai daerah, kota dan negara.

Sebagai wadah keagamaan, gereja memiliki peranan yang penting bagi pengembangan nilainilai keagamaan baik dalam lingkungan masyarakat ataupun keluarga. Salah satu pengemban utama wadah gereja adalah perempuan gereja. Perempuan Gereja mempunyai peranan yang sangat besar dalam pengembangan gereja, karena perempuan mempunyai pengaruh yang baik dan memberikan contoh yang baik bagi orang lain, misalnya dalam kehidupan berkeluarga, perempuan dipandang salah satu kontrol utama dalam menjalin persekutuan keluarga yang penuh cinta kasih kepada Tuhan Yesus Kristus.

GPDI yang bertumbuh di daerah ini, salah satunya berkembang di batu Malang yakni GPDI Sejahtera Junrejo, dengan jumlah jemaat 700 kepala keluarga ini terkumpulan beberapa jemaat yang berasal dari Kajang, Beiji, Batu, dan Malang Selatan. Dengan jumlah jemaat yang hampir 1000 ini, Gereja mempunyai peran serta yang besar untuk menumbuhkan Iman sekaligus kegiatan yang memberikan sisi produktif Jemaat.

Seiring berjalannya waktu, fenomena yang besar yang dialami bangsa kita adalah masalah digitalisasi yang memberikan efek besar bagi seluruh warga Indonesia. GPDI memiliki peranan besar bagi umatnya. Salah satu permasalahan GPDI Sejahtera Junrejo Batu Malang adalah teknologi bagi kaum perempuan tersedianya waktu yang cukup tetapi kurang produktif pemanfaatannya. Namun pada saat yang sama mereka menikmati akses informasi yang banyak melalui jaringan internet di gadget mereka. Jika akses itu tidak dimanfaatkan, tentu tidak ada faedahnya. Maka diperlukan intervensi sosial agar mereka bisa mengisi limpahan manfaat internet dengan sesuatu 
ketrampilan tertentu berbasis teknologi informasi yakni menciptakan usaha bisnis berdagang online atau e-comerce kepada anggota kelompok organisasi perempuan gereja ini. Dengan adanya ketrampila tambahan tersebut, diharapkan perempuan gereja tidak hanya sebagai anggota jemaat yang pasif tetapi juga produktif .

Adapun tujuan dalam pengabdian masyarakat bagi mitra yakni:

- Perempuan yang menjadi anggota Persekutuan di GPDI Sejahtera Junrejo Batu Malang terbentuk ketrampilan melek informasi

- Perempuan yang menjadi anggota Persekutuan di GPDI Sejahtera Junrejo Batu Malang mampu mengelola informasi dan mengubahnya menjadi ketrampilan ekonomi berbasis internet.

- Perempuan yang menjadi anggota Persekutuan di GPDI Sejahtera Junrejo Batu Malang memanfaatkan informasi dalam kehidupan seharihari

- Perempuan yang menjadi anggota Persekutuan di GPDI Sejahtera Junrejo Batu Malang membuka website untuk menciptakan usaha bisnis online/ e-comerce.

Bentuk kongkrit yang bisa kami lakukan selaku tim abdimas (penulis) dari program studi Ilmu Komunikasi adalah pemberdayaan perempuan melalui pemahaman komunikasi pemasaran pada media online (konsep e-commerce) di GPDI Sejahtera Junrejo batu Malang berupa kegiatan :

- Pertama, pemahaman (pendidikan) perempuan melalui program e-commerce agar perempuan GPDI Sejahtera Junrejo Batu Malang dapat melek informasi

- Kedua, pendampingan dalam pengenalan ecommerce pada perempuan GPDI berupa memberi pemahaman mengenai media literasi sekaligus pemahaman dan pemanfaatan media sosial sebagai media interaktif yang potensial dalam kehidupan sehari-hari. Materi yang disajikan diantaranya; Media Literasi, dan Media Sosial (Bijak Menggunakan Media Sosial Dalam Kehidupan sehari-hari). Hal ini bertujuan untuk agar perempuan gereja agar dapat memahami, memanfaatkan, dan mengelola informasi dengan baik.

- Ketiga, pemahanan mengenai komunikasi pemasaran pada media online melalui konsep $e$ commerce sebagai pengetahuan sekaligus pemanfaatan informasi untuk membuka bisnis online.

- Keempat yakni implementasi e-commerce dengan cara mengenalkan sekaligus membuat salah satu bentuk konsep komunikasi pemasaran melalui shopping online. Melalui media sosial seperti Path, Instagram, facebook, Whatapp, dan Line. Kegiatan ini dilakukan untuk membuka peluang usaha bagi perempuan Gereja disela waktu kosongnya dan dapat mengaplikasian dengan mudah dan sederhana.

\section{METODE PELAKSANAAN}

Beberapa metode yang dilakukan dalam kegiatan pengabdian masyarakat, diantaranya;

\section{Pelatihan Media Informasi (Information Literacy) dan Media Sosial}

Dalam pelatihan ini tim akan memberikan gambaran mengenai peranan media informasi di era digital. Serta memberikan pemahaman atau edukasi kepada perempuan gereja mengenai pemanfaatan media sosial dengan baik. Kegiatan ini bertujuan untuk memberikan wacana dan pengetahuan kepada perempuan gereja. Sekaligus memberikan kemampuan untuk menggunakan media informasi berbasis internet sebagai informasi utama, serta. terciptanya perempuan yang kaya informasi, yang dapat melakukan peran sebagai ibu dengan baik. Ibu mampu menghargai dan memanfaatkan informasi yang ada untuk menyelesaikan permasalahan sehari-hari. Misalnya, ibu-ibu lebih arief dalam membagi informasi, sesuatu yang tidak bermanfaat dibuang atau dijauhkan.

\section{Pelatihan Ketrampilan Pemanfaatan Internet sebagai media e-commerce}

Dalam pelatihan ini tim akan memberikan ketrampilan teknis pemanfaatan media sosial, penulisan sederhana untuk mempromosikan kegiatan bisnis yang sudah ditekuni kepada perempuan persekutuan GPDI Sejahtera Junrejo batu Malang. Misalnya: bagaimana cara ibu-ibu menulis pengalaman yang menarik, kiat-kiat apa yang harus diberikan, bagaimana menulis promosi usaha dengan bahasa sedehana dan mudah dipahami oleh pembaca.

Pelatihan dengan memaparkan testomoni individu-individu yang berhasil memanfaatkan kemajuan teknologi informasi dengan telah dibuatnya di media sosial berupa promosi usaha yang telah digeluti. Tahapan ini, ibu-ibu diberikan kesempatan diskusi langsung terkait hambatan dan dukungan terhadap kisah sukses para pioner dibidah bisnis online.

Local Wisdom atau kearifan lokal adalah manisfestasi dari sikap hidup, pengetahuan, maupun strategi kehidupan, berupa aktivitas yang dilakukan oleh masyarakat lokal untuk menjawab berbagai masalah dalam pemenuhan kebutuhan hidupnya. Oleh karena itu, sebuah pemberdayaan perempuan melalui program e-commerce pada organisasi perempuan gereja. 
Partisipasi mitra dalam kegiatan ini ialah dukungan para anggota perempuan gerejawi di GPDI Sejahtera Junrejo Batu Malang dengan memunculkan permasalahan mitra juga dapat berpartisipasi dengan menyediakan tempat untuk ruang pelatihan serta menyosialisasikan kegiatan kepada para anggota. Target luaran kegiatan ini ialah masing-masing anggota dapat menumbuhkan semangat kewirausahaan dibidang e-commerce

\section{SASARAN KEGIATAN}

Sebagai kelompok sasaran yang dituju adalah kaum perempuan gereja GPDI Junrejo Batu Malang

\section{PEMBAHASAN PROFIL MITRA DAN PER- SOALANNYA}

Metode yang digunakan dalam kegiatan pengabdian masyarakat; dengan pendidikan dan pelatihan kepada perempuan gerejawi anggota persekutuan GPDI Sejahtera Junrejo batu Malang. Pendidikan dan pelatihan ini dilakukan untuk menjebatani proses peningkatan pengetahuan mengenai konsep e-commerce. Hal ini secara otomatis memberikan nilai tambah pendidikan dan ketrampilan ibu-ibu mengenai informasi dan manfaat ekonomi dari internet. Pendidikan dan pelatihan ini terbagi menjadi beberapa tahapan, diantaranya:

\section{Pelatihan Media Informasi (Information Literacy) dan Media Sosial}

Kegiatan pelatihan media informasi (information Literacy) merupakan kegiatan yang menjelasakan terkait perubahan dunia terhadap dunia baru. Salah satunya ada multimedia dan pengembangan dunia teknologi. Information literacy ini, dimaksudkan bahwa kegiatan kita kini diperhadapkan dengan informasi-informasi yang bisa didapatkan dari internet, televisi ataupun buku. Prespektif/ sudut pandang yang secara aktif ini digunakan saat berinteraksi dengan media, yaknis sebagai pemahaman dan menerjemahkan makna pesan media.

Kegiatan pelatihan media informasi ini merupakan kegiatan pertama yang dilakukan kepada kaum perempuan di GPDI dengan menjadikan satu kelompok yang terdiri dari 20-70 tahun, sebanyak 30 peserta. Kelas pertama, dua dan tiga diberlakukan sama.

Dalam pelatihan ini, sebagai narasumber adalah Inri Inggrit Indrayani, S. S,IP., M. Si. Beliau banyak menjelasakan tentang information literasi dengan penggunaan internet di dunia yang mengalami kenaikan tajam, pada tahun 2016 sejumlah 132,7 juta orang di Indonesia sebagai pengguna internet, dan kini berubah menjadi 256,2 juta orang. hal ini mengindikasikan kenaikan 51.8 persen dibandingkan jumlah pengguna internet pada 2014 lalu. Survei yang dilakukan APJI pada tahun 2014 hanya ada 88 juta pengguna internet.

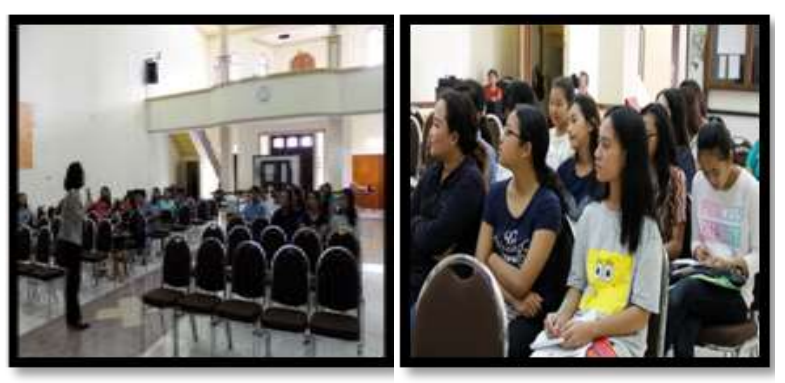

Gambar 1. Peserta Mendengarkan Cermahah dari Inri Inggrit Indrayani, S. S,IP., M. Si. (Sumber: Dokumentasi, 2017)

Tujuan dari kegiatan ini adalah memberikan pengetahuan kepada kaum perempuan gereja terkait penggunaan internet pada umumnya. Salah satu penggunaan internet yang seringkali kita jumpai adalah mobile phone atau handphone (HP), dimana HP ini sangat memudahkan kita untuk menggunakan jaringan internet melalui sosial media. Pemanfaatan sosial media memberikan nilai positif dan negatif.

Namun yang perlu diketahui oleh kaum perempuan gereja adalah informasi berada dalam pesan media. Bisa media apa saja, baik buku, majalah, internet, video dan games. Pengetahuan yang bisa kita dapatkan adalah sebagai refleksi kita terhadap informasi yang kita bisa interpretasikan dan memiliki ketrampilan atau skill yang perlu dikembangkan untuk berlatih membaca media.

Sedangkan pelatihan berikutnya adalah terkait dengan media sosial. kegiatan pelatihan media sosial ini bertujuan memberikan pengetahuan kepada kaum perempuan terkait etika berkomunikasi menggunakan media internet atau media sosial serta apa saja pemanfataan dari penggunaan media sosial ini. Pada tahap ini peserta diajak untuk membuka pikirannya terkait dengan penggunaan media sosial yang saat ini disalahgunakan oleh masyarakat umumnya. Banyaknya fenomenafenomena penyalahgunaan atau dampak negative bagi pelaku media sosial, bisa menimbulkan hukuman bagi sang pelaku media sosial. Disini bapak Gatut Priyowidodo, Ph.D menyampaikan bagaimana sejarah media ditemukan, yang tadinya kita harus menuruti perintah media, saat ini keterbukaan informasi sudah berbeda. Media dapat dipengaruhi oleh perilaku manusia dan manusia tidak harus melakukan perintah sesuai yang media katakan. Fenomena yang sangat besar dihadapi oleh masyarakat pada umunyanya adalah media sosial. Penggunaan media sosial sangatlah besar. Dulu penggunaan internet hanya sebatas cek dan ricek atau konvensional, saat ini sudah menjadi dua 
arah, bahkan mengabaikan cek dan ricek dan masyarakat berhak membuat sebuah pemberintaan atau yang seringkali disebut dengan 2.0. media

Indonesia memiliki urutan nomer 1 sebagai pelaku media sosial. dalam hal ini semua orang bisa menggunakan sosial media dan bisa memanfaatkan sosial media.

Gatut Priyowidodo, Ph.D, mengharapkan dengan adanya pelatihan ini, jemaat GPDI khususnya kaum perempuan bisa memanfaatkan media sosial dengan baik dan menggunakan katakata yang bisa dimaknai baik tanpa harus mencelakai orang lain.

Karena etika pada dasarnya dapat diartikan sebagai suatu kesediaan jiwa seseorang untuk senantiasa patuh kepada seperangkat aturan-aturan kesusilaan, fungsinya adalah bisa mengatur tindakan-tindakan seseorang untuk berbuat baik dan menghidari perbuatan buruk. Atau mengetahui mana yang tidak sesuai dan mana yang sesuai. Akibatnya, bisa terjadi spill over information atau informasi yang meluber, tidak bisa dibedakan lagi mana yang sesuai dan tidak. Dikarenakan saat ini banyaknya informasi-informasi yang bersifat hoax atau tidak sesuai keberadaannya.

Pelatihan yang kedua ini bersifat seminar/ ceramah. Kaum perempuan diajak untuk bisa memahami bagaimana cara berkomunikasi yang baik dan sekaligus memanfaatkan media dengan sesuai. Tujuannya untuk melatih komunikasi personal atau kelompok di media dan bisa saling memberikan feedback yang positif. Dengan adanya pelatihan etika berkomunikasi, peserta dapat saling memahami dan mengetahui bagaimana cara yang lebih efektif dalam pemanfataan media sosial.

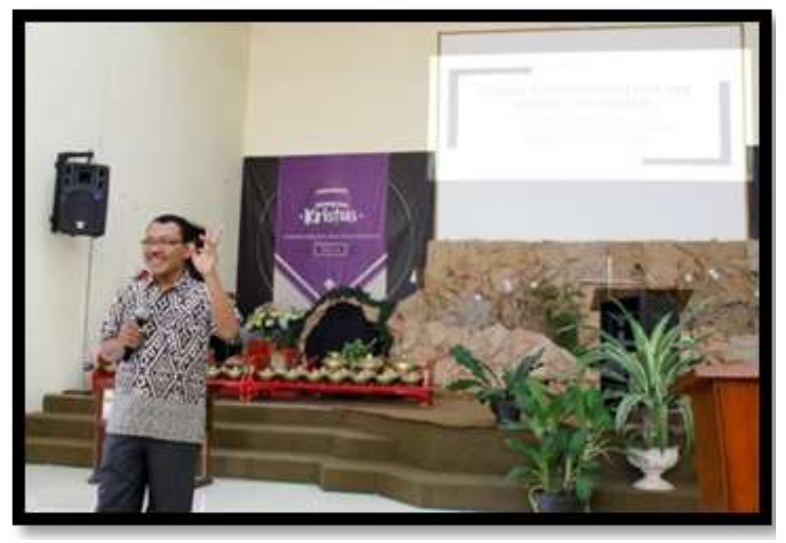

Gambar 2. Narasumber Gatut Priyowidodo, Ph.D Sedang Memberikan Pelatihan Etika Berkomunikasi Dalam Media Sosial (Sumber: Dokumentasi, 2017)

\section{Pelatihan Ketrampilan Pemanfaatan Internet (Media Sosial) sebagai Media E-Commerce}

Pemanfaatan kemajuan teknologi informasi di Indonesia tidak hanya monopoli oleh masyarakat perkotaan tetapi juga sudah merambah di beberapa daerah-daerah khususnya. Sejak tahun 2012, pemerintah mencanangkan gerakan digital teknologi masuk kedaerah-daerah khusunya kecamatan hingga seluruh wilayah Indonesia yang sudah semakin terintergrasi. Keuntungan lain, akses informasi semakin mudah dan masyarakat dapat memanfaatkan usaha produktif kreatif. Usaha produktif kreatif ini memunculkan istilah baru yakni technopreneurship yakni pengembangan jenis kewirausahaan konvensional yang secara modern mampu mengapdopsi kemajuan teknologi informasi sebagai basis kekuatan usahanya.

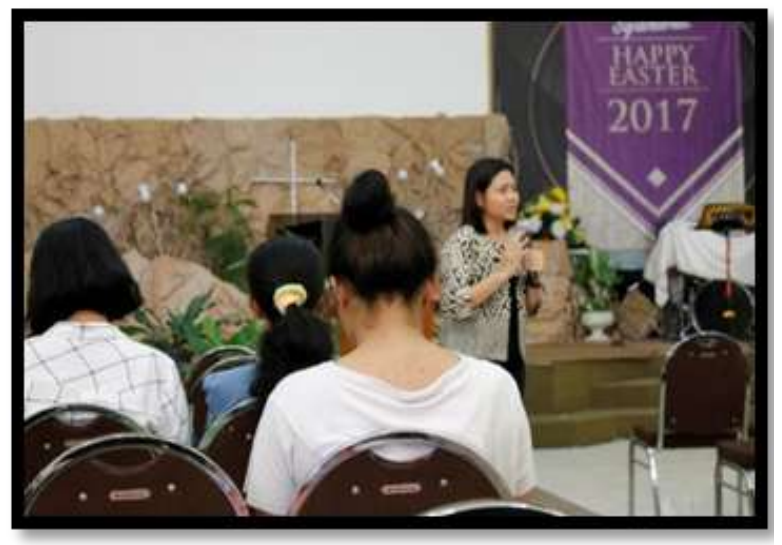

Gambar 3. Narasumber Yustisia Ditya Sari, S. Sos., M. I. Kom Sedang Memberikan Pelatihan Pemanfaatan Internet (Media Sosial) Sebagai Media E-Commerce (Sumber : Dokumentasi, 2017)

Dalam kegiatan inilah, peserta harus memahami pentingnya dasar sebuah informasi. Dasarnya adalah komunikasi. Menurut Carl I. Hovland, komunikasi merupakan sebuah proses dimana seseorang individu atau komunikator mengoperkan stimulant biasanya dengan lambing-lambang Bahasa (verbal maupun non verbal) untuk mengubah tingkah laku orang lain.

Dengan adanya komunikasi maka pesan dapat diterima dan dimaknai dengan baik oleh si penerima pesan.

Dalam pelatihan ini, narasumber juga menyampaikan bagaimana cara memanfaatkan media sosial dengan melalui kegiatan e-commerce. e-commerce (eletronik commerce) merupakan sebuah kegiatan menjual produk-produk dari jasa secara online, sedangkan media tang digunakan adalah website/media sosial. Dari kegiatan e-commerce ini dampaknya mengubah perekonomian, struktur pasar, industry produk dan jasa serta aliran distribusi dan pasar tenaga kerja. Adapun contohcontoh model e-commerce di Indonesia yakni Classfields/listing atau iklan baris, marketplace customer to customer, shopping mall, toko online business to customer, serta toko online di media sosial. berikut salah satu contoh model bisnis $e$ commerce di Indonesia. 


\section{Kegiatan Pembuatan Media E-Commerce (Shopping Online)}

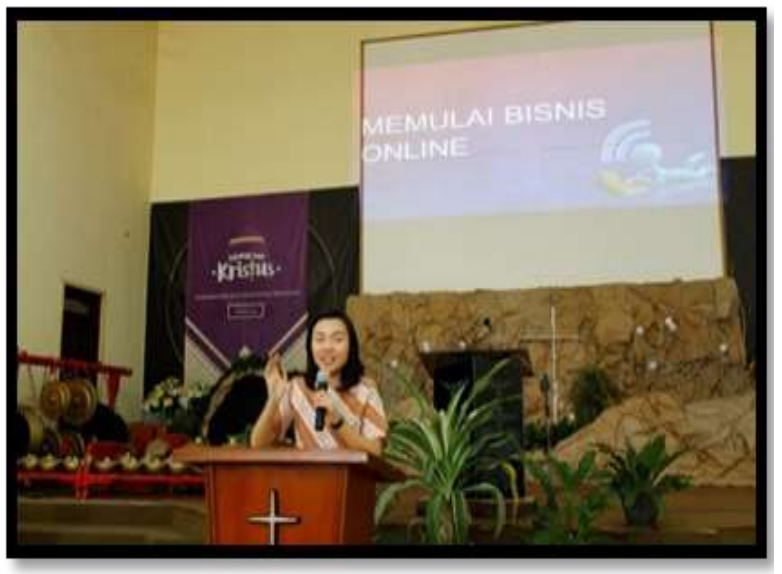

Gambar 4. Narasumber Monica Yapilando Sedang Memberikan Pelatihan Pembuatan Media E-Commerce (Shopping Online)

Dalam kegiatan pelatihan keempat ini, dilakukan implementasi atau simulasi pembuatan $e$ commerce. Salah satu kegiatan yang dilakukan adalah pembuatan shopping online. Dikarenakan bisnis ini yang paling mudah dilakukan dan dibuat oleh peserta atau calon pebisnis e-commerce. Kegiatan ini dilakukan oleh Monica Yapilando, yang merupakan mahasiswa UK Petra dari program studi Ilmu Komunikasi telah melakukan bisis shopping online sejak 5 tahun yang lalu.

Kegiatan ini merupakan pelatihan untuk memberikan kemampuan peserta untuk lebih semakin aktif dan bisa mengembangkan diri. Tujuannya untuk memberikan pengetahuan dan sikap peserta untuk bisa melakukan kegiatan $e$ commerce. Adapun tahapan-tahapan yang perlu dilakukan dalam membuat toko online melalui media sosial yakni;

Tahapan pertama, menentukan nama atau merek yakni sebelum memulai bisnis online ada beberapa hal yang perlu dipersiapkan misalnya ingin menjual makanan, maka nama/merek yang akan dipilih/ditentukan harus berhubungan dengan makanan yang dijual. Atau bisa dari nama pencetus/keterkaitan dengan penemu, bisa jadi memakai nama/merek yang unik. Berikut ini contoh nama brand yang dibuat oleh narasumber.

Sedangkan tahapan kedua, adalah menampilkan foto produk. Dalam tahapan ini, foto produk harus semenarik mungkin. Foto produk bisa dari diri kita sendiri/dari orang lain. Foto produk fungsinya adalah supaya orang dapat dimengerti produk apa saja yang dijual dan sedemikian rupa, foto produk adalah sesuai dengan barang aslinya (real picture). Berikut ini contoh gambar foto produk yang bisa digunakan atau dipakai di shopping online.

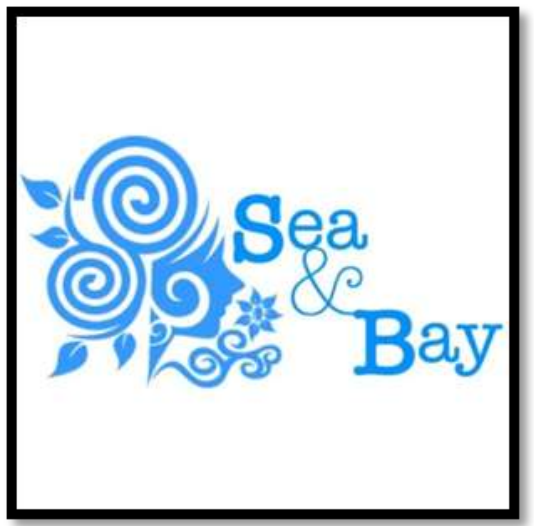

Gambar 5. Contoh Nama Brand Yang digunakan Sebagai Nama di Shopping Online (Sumber ; Dokumentasi, 2017)

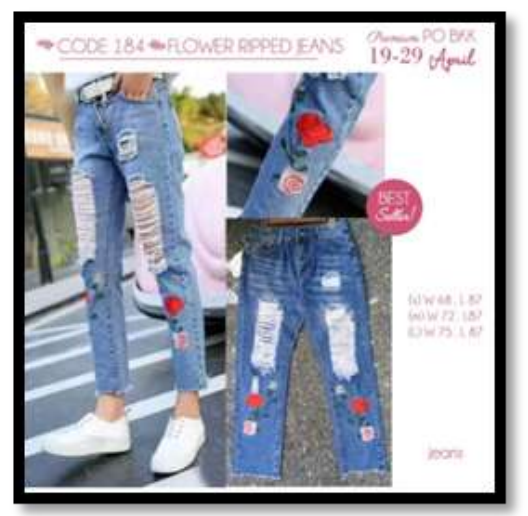

Gambar 6. Contoh Foto Produk Yang digunakan Sebagai Nama di Shopping Online (Sumber: Dokumentasi, 2017)

Tahapan berikutnya, tahap ketiga yakni membuat kata-kata/ caption. Tahapan ini merupakan deskiripsi/caption yang diginakan untuk mendukung suatu produk. Hal ini menjelaskan seperti ; nama produk, jenis produk, harga, lokasi penjualan, transfer via ap, bisa dikontak lewat apa saja dan menjelaskan detail produk agar orang dapat mengerti produk itu dengan jelas sebelum membeli. Berikut ini contoh gambar caption/kata-kata yang bisa digunakan atau dipakai di shopping online;

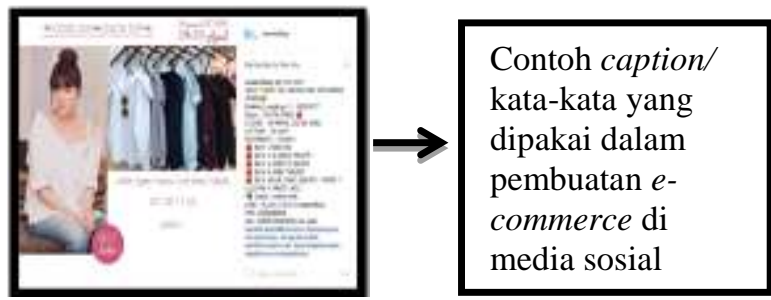

Gambar 7. Contoh Caption/Kata-Kata Yang digunakan Sebagai Nama di Shopping Online (Sumber: Dokumentasi, 2017)

Dan tahapan terakhir, yakni tahap keempat mulai bagikan atau share. Sebuah bisnis dikatakan online ketika dibagikan ke dunia maya/online. Setelah melakukan 3 tahap diatas, dapat mulai membagikan ke sosialisasi media, antara lain ; facebook, 
Instagram, twitter, shopee, carousel, line group, whatsapp, blackberry messeger. Setalah dibagikan maka anda telah memulai bisnis online.

Dalam pelatihan ini tidak hanya berisikan materi dalam pembuatan e-commerce di media sosial. namun dalam pelatihan ini, juga melakukan simulasi dalam pembuatan e-commerce salah satunya di media sosial. salah satu aktivitas yang dilakukan adalah dengan membagi kelompok menjadi 4 kelompok.

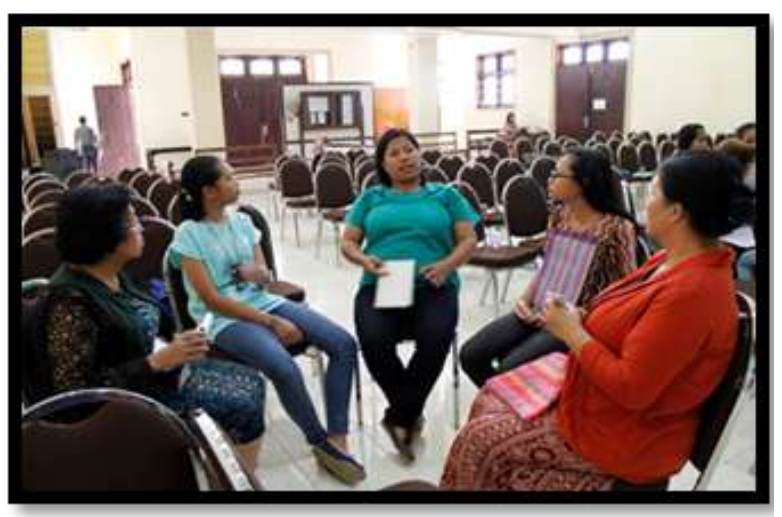

Gambar 7. Pembagian Kelompok, Kelompok Mendiskusikan Rancangan E-commerce yang akan dibuat (Sumber: Dokumentasi, 2017)
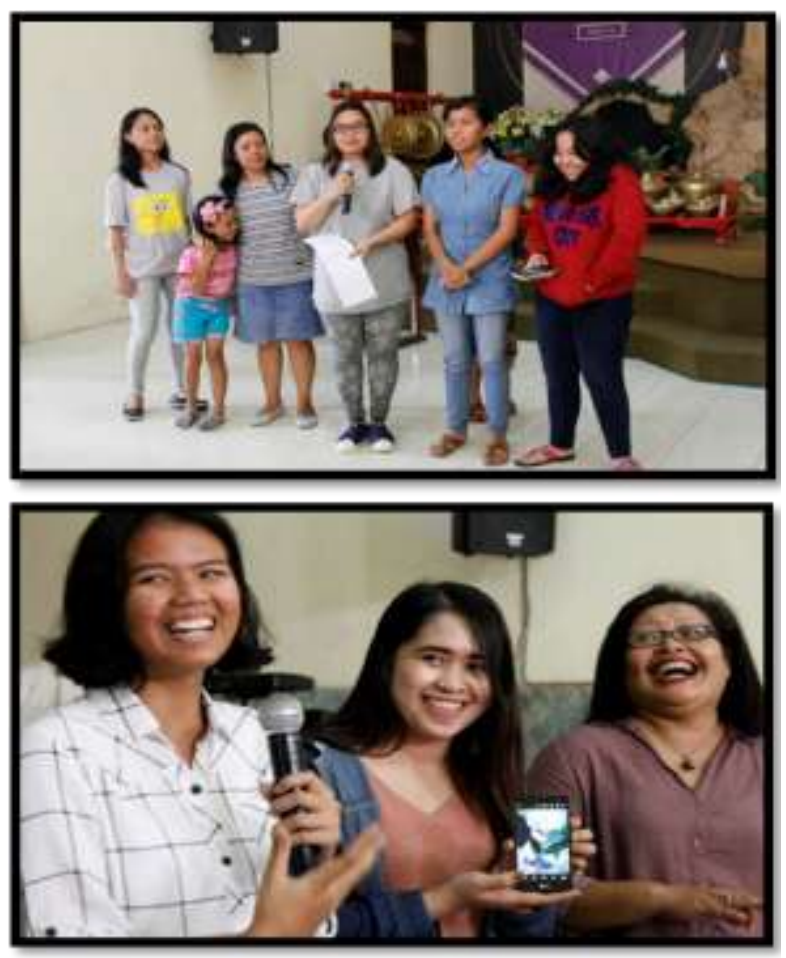

Gambar 8. Kelompok Mempresentasikan Rancangan Ecommerce yang dibuat (Sumber: Dokumentasi, 2017)

Kelompok/peserta diberi masing-masing tugas untuk membuat empat tahapan yang telah diinformasikan tadi. Setalah mereka melakukan pembuatan nama produk, foto produk, pembuatan kata-kata. Peserta diminta untuk mempresentasikan kepada peserta lainnya.

\section{KEGIATAN MONITORONG DAN EVALUASI}

Monitoring dan evaluasi dilakukan setelah selesai pelatihan. Saat itu tanggal, 10-11 Jui 2017 kami (selaku tim pengabdi) berkunjung ke gereja GPDI dan bertemu dengan ibu Yelly selaku Ketua kaum perempuan gereja, banyak hal yang sempat kami tanyakan kepada beliau salah satunya adalah implementasi perempuan gereja terhadap kegiatan e-commerce. Dengan bertambahnya pengetahuan dan pengalaman terkait pemanfaatan media social, maka ibu-ibu dan pemuda gereja semakin sadar, bahwa media social juga memiliki dampak ekonomi produktif. Misalnya bisa digunakan untuk jualan kue atau barang-barang lainnya, melalui media what app dikarenakan media tersebut lebih memudahkan ibu-ibu untuk menggunakannya.

\section{KESIMPULAN DAN SARAN}

Dengan diselesaikannya legiatan pengabdian masyarakat oleh pengabdi dengan mitra gereja yakni GPDI Sejahtera Junrejo Batu-Malang, dapat ditarik kesimpulan sebagai berikut;

1. Kaum Perempuan Gereja telah memiliki pengetahuan mengenai literasi media atau ketrampilan melek informasi. Ibu-ibu bisa semakin sadar pentingnya informasi sesuai perkembangan yang saat ini terjadi. Dengan adanya pengetahuan terkait dengan media informasi kaum perempuan kaya informasi sehingga dapat digunakan sebagai peran serta warga jemaat yang bisa menunjang pelayanan di ereja secara maksimal, serta menghargai dan memanfaatkan secara maksimal media informasi.

2. Melalui kegiatan pelatihan etika berkomunikasi salam media sosial, kaum perempuan gereja GPDI Sejahtera dapat bijak menggunakan media sosial untuk kehidupan sehari-hari baik dalam menulis ataupun memanfaatkannya.

3. Perempuan yang menjadi anggota persekutuan GPDI Sejahtera Junrejo batu Malang mampu mengelola informasi dan mengubahnya menjadi ketrampilan ekonomi berbasis internet. Di sini, ibu-ibu mampu menopang perekonomian keluarga melalui kegiatan yang produktif dengan memfaatkan media sosial sebagai bisnis onlinenya.

4. Perempuan yang menjadi anggota persekutuan GPDI Sejahtera Junrejo batu Malang memanfaatkan informasi dalam kehidupan seharihari. Di sini diharapkan para ibu-ibu tersebut tidak hanya menggunakan gadget sebagai media informasi bualan, tetapi dapat digunakan sebagai media iklan atau menawarkan produk yang bisa dijual ke pihak lain. 
Saran yang dapat diberikan untuk kegiatan selanjutnya adalah;

1. Adanya follow up kepada GPDI Sejahtera khususnya kaum perempuan gereja mengenai aktivitas yang dilakukan dimedia sosial, lebih tepatnya penggunaan media sosial sebagai media e-commerce.

2. Perlunya pelatihan lanjutanya untuk meningkatkan komunikasi promosi bagi produk yang dijualkan di media sosial (e-commerce) sebagai peningkatan penjualan

3. Kerjasama antara perguruan tinggi dan gereja GPDI dapat dilajutkan untuk pelatihan yang frekuensinya lebih sering dengan materi yang lebih bervariasi.

\section{UCAPAN TERIMA KASIH}

Para pengabdii masyarakat igin mengucapkan terima kasih sebesar-besarnya kepada :

1. LPPM (Lembaga Penelitian dan Pengabdian Masyarakat) UK Petra yang telah membantu memfasilitasi kegiatan ini

2. Fakultas Ilmu Komunikasi UK Petra

3. Program Studi Ilmu Komunikasi UK Petra

4. Pdt. Yohanes B. Malauw, S. Th., Gembala Sidang Gereja GPDI Junrejo Batu Malang

5. Yonathan Malauw, sekretaris gereja GPDI Junrejo Batu Malang

6. Kaum Perempuan GPDI Junrejo Batu Malang

\section{DAFTAR PUSTAKA}

Creeber, G. \& R. Martin. (2009). Digital Cultures: Understanding New Media. Berkshire, England: McGraw-Hill.
Fuctis, Christian. (2011). Foundations of Critical Media and Informations Studies. USA \& Canada: Routledge

Griffin, A., (2011). Social Media vs. Traditional Media: Competing or Complementary Channels? http://www.griffinstrategies.com/_blog/Griffin_ Strategies_Blog/

Jamie, (2013). Digital and Traditional Media: More Similar Than You Think http://www.raidious. com/owned-media/digital-and-traditionalmedia-more-similar-than-you-think/

Leaning, Marcus. (2009). Issues In Informatons And Media Literacy: Criticism, History And Policy. USA : Informing Science Press

Majelis Agung, (2010). Tentang GKJW http://www. gkjw.web.id/sekilas-mengenal-gkjw

Nagasvare D/O M. Krishnasamy(2012). New Media vs Traditional Mediahttp:/www.aibd.org.my/ node/1226post/Social_Media_vs_Traditional_M edia_Competing_or_Complementary_Channels/

Salman,A., Faridah I., Abdullah,M., Mustaffa,N., \& Mahbob,M.H., (2011). The Impact of New Media on Traditional Mainstream Mass Media. The Innovation Journal: The Public Sector Innovation Journal, Vol. 16(3), 1-11

Wright, D.K., \&Burson, H. (2012). Examining How Social and Emerging Media Have Been Used in Public Relations Between 2006 and 2012: A Longitudinal Analysis Paper was presented at the 12th Annual BledCom Conference in Bled, Slovenia, July 6. 